\title{
A synopsis of Bambusoideae (Poaceae) in Lombok, Indonesia
}

\author{
I PUTU GEDE P. DAMAYANTO ${ }^{1,2, \vartheta}$, HIMMAH RUSTIAMI ${ }^{2}$, MIFTAHUDIN ${ }^{3}$, TATIK CHIKMAWATI ${ }^{3, \bullet \varphi}$ \\ ${ }^{1}$ Plant Biology Graduate Program, Department of Biology, Institut Pertanian Bogor. Jl. Raya Dramaga, Kampus IPB Dramaga, Bogo r16680, West Java, \\ Indonesia. Tel.: +62-251-8622642, `email: parlida.damayanto.tab@gmail.com \\ ${ }^{2}$ Herbarium Bogoriense, Botany Division, Research Center for Biology, Indonesian Institute of Sciences. Jl. Raya Jakarta-Bogor Km 46, Cibinong, Bogor \\ 16911, West Java, Indonesia \\ ${ }^{3}$ Department of Biology, Institut Pertanian Bogor. Jl. Raya Dramaga, Kampus IPB Dramaga, Bogor 16680, West Java, Indonesia. \\ Tel.: +62-251-8622642."vemail: tchikmawati@gmail.com
}

Manuscript received: 13 August 2020. Revision accepted: 5 September 2020.

\begin{abstract}
Damayanto IPGP, Rustiami H, Miftahudin, Chikmawati T. 2020. A Synopsis of Bambusoideae (Poaceae) in Lombok, Indonesia. Biodiversitas 21: 4489-4500. There is little documentation of bamboo on Lombok. Non-native Indonesian bamboos have been reported occurring in Lombok. As such, suspicious bamboo specimens and information in those reports need to be examined and possibly re-determined. This study aimed to provide updated taxonomical information of bamboo species in Lombok and to investigate the accuracy of previous studies regarding the existence of several non-native Indonesian bamboo species on the island (i.e. they do not have original distribution in Indonesia). Data from fieldwork were combined with specimens in Herbarium Bogoriense to create a synopsis of bamboo in Lombok and to develop an identification key to the species. Eleven species of bamboos in Lombok were reported from this study, namely Bambusa glaucophylla, B. maculata, B. multiplex, B. spinosa, B. vulgaris, Dendrocalamus asper, Gigantochloa apus, G. atter, Schizostachyum brachycladum, S. lima, and Thyrsostachys siamensis. Several doubtful species (B. albustiata, B. ventricosa, Guadua angustifolia, S. jaculans, Pseudosasa japonica) were presented to clarify the existence of a non-native Indonesian bamboo in Lombok. Moreover, there is not enough evidence to state Dinochloa sp. occurred in Lombok. The results of this study can be used by stakeholders for bamboo identification and as the baseline taxonomic account for future studies and conservation of bamboo species in Lombok.
\end{abstract}

Keywords: Bamboo, diversity, identification key, Indonesia, Lombok

Abbreviations: BM: The Natural History Museum, BO: Herbarium Bogoriense, GOET: Herbarium of Universität Göttingen, K: Kew Herbarium, L: Naturalis Biodiversity Center, Nationaal Herbarium Nederland, M: Herbarium of Botanische Staatssammlung München, P: Muséum National d'Histoire Naturelle, US: United States National Herbarium

\section{INTRODUCTION}

Lombok is an island in the Lesser Sunda archipelago, flanked by the islands of Bali and Sumbawa. The island is administratively located in West Nusa Tenggara Province, Indonesia. Many parts of the island have mountainous terrain with the highest point is Mt. Rinjani with an altitude of 3726 meters above sea level (m asl.) (BPSPNTB 2018). From the ecoregion perspective, Lombok is categorized as seasonally dry tropics. The ecology of Lombok's seasonal and mountainous landscapes lacks investigation (Brearley et al. 2019). Likewise, the flora is not widely studied, reflected by little documentation of the island's bamboo diversity.

Botanical exploration in Lombok began in 1845 . Steenis-Kruseman (1950) reported that many researchers had explored Lombok, such as MacGillivray in 1845, Zollinger in 1846, Wallace in 1856, Kesslitz in 1886, Koorders in 1894, Vorderman in 1894, Everett in 1896, Bosse in 1899, Fairchild in 1900, Ernst in 1906, Elbert in 1909, Kawakami in 1911, Toxopeus in 1921, Tengwall in 1925, Rensch-Maier in 1927, Straelen in 1929, Voogd in 1933-1936, Veen in 1936, Bloembergen in 1939 and
Botma in 1947. Despite these explorations, bamboo diversity in Lombok has not been well documented (Voogd 1941; Tobe et al. 2010).

Bamboos belong to the family Poaceae and subfamily Bambusoideae. Bamboo has two types of stems namely rhizomes which are located underground and culms which are located aboveground (Wong 2004), in which both stem types have nodes. The culms of bamboo generally grow erect, but some others climb or scramble (Judziewicz et al. 1999). The culms are generally cylindrical and hollow, but some are rectangular and solid or narrowly hollow (Widjaja 2001a). The branches generally grow above or to the right at the nodes of the culm (Widjaja 2001b), some also grow under the nodes (Wong and Dransfield 2016). Bamboo culm-sheath consists of blades, auricles, and ligules which vary in shape and size. The inflorescence is very rarely found and some bamboo flower once every 150 years (Janzen 1976). The base unit of a bamboo inflorescence is known as a pseudospikelet, consisting of one to several single flowers. Each flower consists of lemma, palea, stamens, and pistils (Judziewicz et al. 1999), and some species have one to three lodicules (Wong 2004). 
Table 1. Bamboo diversity studies in certain area of Lombok, West Nusa Tenggara Province, Indonesia

\begin{tabular}{lcl}
\hline Location & $\begin{array}{c}\text { Numbers of } \\
\text { species found }\end{array}$ & References \\
\hline Central Lombok & 14 & $\begin{array}{l}\text { Peneng et al. } \\
(2005)\end{array}$ \\
$\begin{array}{l}\text { Tiu Pupus riverbank, North } \\
\text { Lombok }\end{array}$ & 9 & $\begin{array}{l}\text { Huzaemah et al. } \\
(2016)\end{array}$ \\
$\begin{array}{l}\text { Meninting riverbank, West } \\
\text { Lombok }\end{array}$ & 8 & Putri et al. (2016) \\
$\begin{array}{l}\text { Senaru forest, North Lombok } \\
\text { Kedome riverbank, East }\end{array}$ & 5 & $\begin{array}{l}\text { Rini et al. (2017) } \\
\text { Lombok }\end{array}$ \\
$\begin{array}{l}\text { Senggigi, West Lombok } \\
\text { Peak of Mt. Pujut, Mandalika, et al. } \\
\text { Central Lombok }\end{array}$ & 5 & $\begin{array}{l}\text { (2018) } \\
\text { Semoya riverbank, West }\end{array}$ \\
$\begin{array}{l}\text { Lombok } \\
\text { Keremit riverbank, East }\end{array}$ & 5 & $\begin{array}{l}\text { Rizkillah (2018) } \\
\text { Susan et al. } \\
\text { Lombok }\end{array}$ \\
\hline
\end{tabular}

Bamboo fruit can be a caryopsis or bacoid (Judziewicz et al. 1999). Bamboo naturally occurs in all continents except Europe and Antarctica (Clark et al. 2015). There are 1670 species and 125 genera of bamboo in the world (Soreng et al. 2017). Among these, 176 species of 24 genera are found in Indonesia (Widjaja 2019). The first report of bamboo diversity in Lombok was by Prawiroatmodjo and Padmono in 1976. Several years later, Widjaja (2001a) published a guidebook of bamboos in the Lesser Sunda Islands. Widjaja (2001a) reported six species of bamboos in Lombok. Based on a checklist of Lombok flora (Rustiami and Sulistyaningsih 2020), there is only one bamboo species (Bambusa vulgaris) that occurred in Lombok. Several bamboo studies have been carried out locally in Lombok (Table 1).

This study aimed to provide updated taxonomical information of bamboo species in Lombok and to investigate the accuracy of previous studies regarding the existence of several non-native Indonesian bamboo species in the island (i.e. they do not have original distribution in Indonesia). This investigation is important as some studies mentioned bamboo species that have never been officially reported occurring in Lombok or even in Indonesia, for example, Bambusa ventricosa (Peneng et al. 2005), Guadua angustifolia, Schizostachyum jaculans (Putri et al. 2016; Huzaemah et al. 2016; Santi et al. 2019) and Pseudosasa japonica (Rizkillah 2018). Therefore, those specimens need to be examined and possibly redetermined. The results of this study can be used by stakeholders for bamboo identification and as the baseline taxonomic account for future studies and conservation of bamboo species in Lombok.

\section{MATERIALS AND METHODS}

\section{Study period and area}

Fieldwork was conducted in March 2018 and November 2019 in Lombok Island, West Nusa Tenggara Province, Indonesia. Geographically, Lombok Island was located at $8^{\circ} 13^{\prime} 34.8^{\prime \prime} \mathrm{S}$ to $8^{\circ} 56^{\prime} 47.7^{\prime \prime} \mathrm{S}$ and $115^{\circ} 49^{\prime} 40.6^{\prime \prime}$ E to $116^{\circ} 43^{\prime} 12.1^{\prime \prime}$ E with an altitude of 0-3726 m. Several areas with chances of finding bamboos were visited (Table 2 and Figure 1).

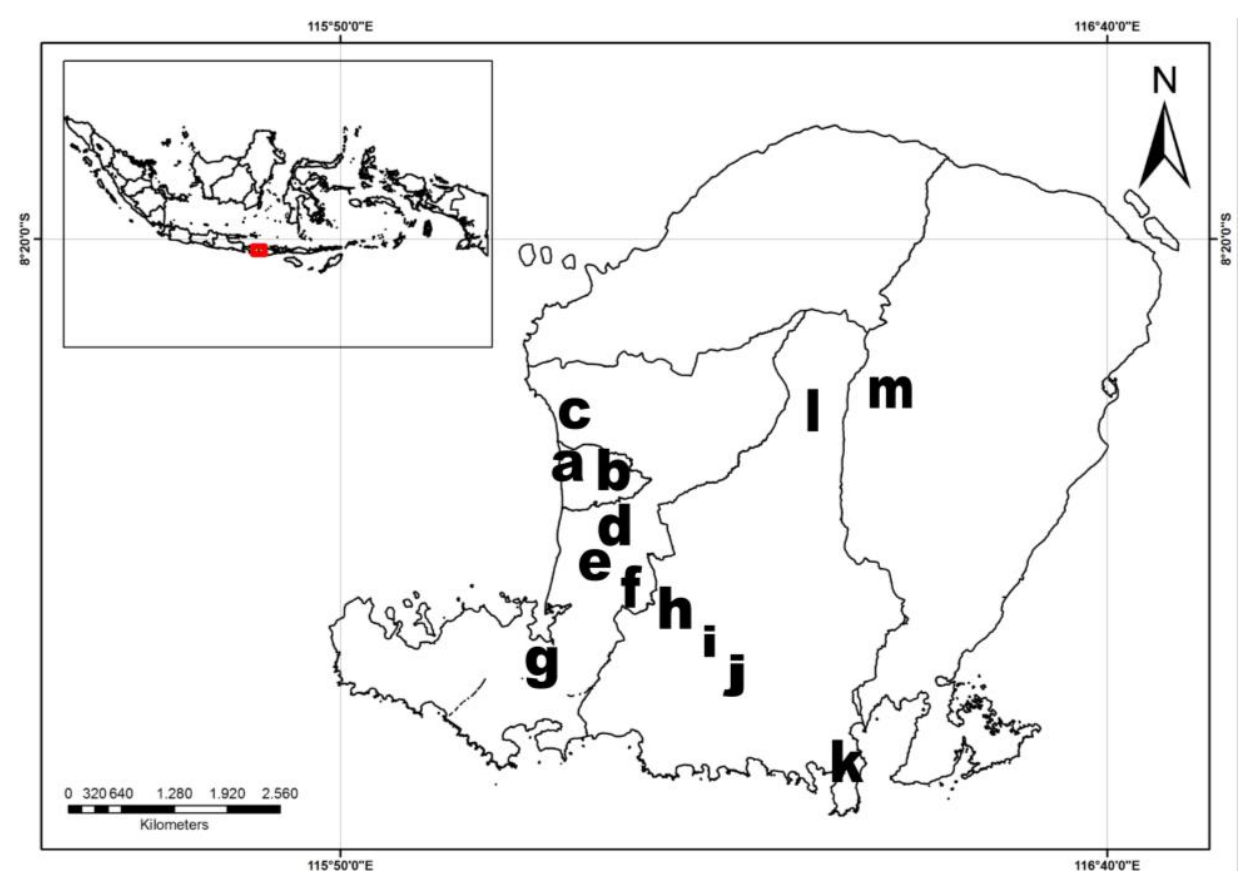

Figure 1. The locations (villages) of the fieldwork in Lombok Island, West Nusa Tenggara, Indonesia. A. Dayan Peken, B. Cakranegara, C. Meninting, D. Bagik Polak, E. Beleke, F. Kuripan, G. Marije, H. Sukarana, I. Tanak Awu, J. Batubolong, K. Mertak, L. Wajagesang, M. Kembang Kuning 
Table 2. The locations of the fieldwork in Lombok Island, West Nusa Tenggara, Indonesia

\begin{tabular}{|c|c|c|c|c|c|}
\hline \multicolumn{3}{|c|}{ Location } & \multirow{2}{*}{ Coordinate } & \multirow{2}{*}{$\begin{array}{l}\text { Altitude } \\
\text { (m asl.) }\end{array}$} & \multirow{2}{*}{$\begin{array}{l}\text { Major surrounding } \\
\text { landscape }\end{array}$} \\
\hline District & Sub-district & Village & & & \\
\hline Central Lombok & Jongat & Sukarana & $8^{\circ} 41^{\prime} 57.9 ” \mathrm{~S}, 116^{\circ} 12^{\prime} 09.2^{\prime \prime} \mathrm{E}$ & $80-100$ & Paddy field and settlement \\
\hline Central Lombok & Pujut & Mertak & $8^{\circ} 53^{\prime} 38.0^{\prime \prime} \mathrm{S}, 116^{\circ} 21^{\prime} 59.0^{\prime \prime} \mathrm{E}$ & $15-100$ & Secondary forest \\
\hline Central Lombok & Pujut & Tanak Awu & $8^{\circ} 45^{\prime} 52.4^{\prime \prime} \mathrm{S}, 116^{\circ} 15^{\prime} 46.7^{\prime \prime} \mathrm{E}$ & $90-100$ & Paddy field and settlement \\
\hline Central Lombok & Southwest Praya & Batubolong & $8^{\circ} 42^{\prime} 41.4^{\prime \prime} \mathrm{S}, 116^{\circ} 12^{\prime} 50.0^{\prime \prime} \mathrm{E}$ & $80-90$ & Paddy field and settlement \\
\hline Central Lombok & Kompang & Wajagesang & $8^{\circ} 36^{\prime} 00.5^{\prime \prime} \mathrm{S}, 116^{\circ} 22^{\prime} 11.5^{\prime \prime} \mathrm{E}$ & $380-500$ & Bamboo garden \\
\hline East Lombok & Sikur & Kembang Kuning & $8^{\circ} 31^{\prime} 57.9$ " S, $116^{\circ} 25^{\prime} 30.6$ " E & $670-700$ & Bamboo garden \\
\hline Mataram & Ampenan & Dayan Peken & $8^{\circ} 34^{\prime} 22.3^{\prime \prime} \mathrm{S}, 116^{\circ} 04^{\prime} 41.8^{\prime \prime} \mathrm{E}$ & $10-15$ & Settlement \\
\hline Mataram & Mataram & Cakranegara & $8^{\circ} 35^{\prime} 04.8^{\prime \prime} \mathrm{S}, 116^{\circ} 07^{\prime} 30.8^{\prime \prime} \mathrm{E}$ & $25-35$ & Settlement \\
\hline West Lombok & Labu Api & Bagik Polak & $8^{\circ} 38^{\prime} 08.7^{\prime \prime} \mathrm{S}, 116^{\circ} 07^{\prime} 34.6^{\prime \prime} \mathrm{E}$ & $20-30$ & Bamboo garden \\
\hline West Lombok & Kuripan & Kuripan & $8^{\circ} 40^{\prime} 21.1 " \mathrm{~S}, 116^{\circ} 10^{\prime} 16.9{ }^{\prime \prime} \mathrm{E}$ & $30-40$ & Paddy field and settlement \\
\hline West Lombok & Gerung & Beleke & $8^{\circ} 39^{\prime} 35.5^{\prime \prime} \mathrm{S}, 116^{\circ} 07^{\prime} 50.6$ " E & $20-25$ & Paddy field and settlement \\
\hline West Lombok & Batu Layar & Meninting & $8^{\circ} 33^{\prime} 16.0^{\prime \prime} \mathrm{S}, 116^{\circ} 04^{\prime} 32.0^{\prime \prime} \mathrm{E}$ & $5-10$ & River \\
\hline West Lombok & Lembar & Marije & $8^{\circ} 47^{\prime} 28.0^{\prime \prime} \mathrm{S}, 116^{\circ} 03^{\prime} 11.0^{\prime \prime} \mathrm{E}$ & $200-250$ & Shrubs and dry field \\
\hline
\end{tabular}

\section{Procedures}

The method of collection of bamboo prescribed by McClure (1945) and Rugayah et al. (2004) and collection of herbarium specimens by Djarwaningsih et al. (2002) was followed. Since bamboos are rarely flowering (Janzen 1976), the sterile material was also collected. Supporting data was recorded and photographs of the fresh specimens were taken. All specimens were stored in the Herbarium Bogoriense (BO), Research Center for Biology, Indonesian Institute of Sciences (LIPI).

The specimens were then identified by matching with BO specimens and using literature on the bamboo of the Lesser Sunda Islands (i.e. Soenarko 1977; Dransfield 1996; Dransfield and Widjaja 1995; Wong 1995; Widjaja 1987, 1997, 2001a, b; Widjaja et al. 2004, 2005; Damayanto and Widjaja 2016). Observations of BO specimens were also carried out from other locations (if needed).

\section{Data analysis}

Morphological characters were analyzed and described descriptively. From these sources, a synopsis of bamboo in Lombok was created and arranged alphabetically. An identification key to the species was developed. Herbarium abbreviation followed Holmgren et al. (1981) and Girmansyah et al. (2006, 2018) or website sweetgum.nybg.org. The accepted status of every species names was determined by following Vorontsova et al. (2016) or websites such as ipni.org, powo.science.kew.org, tropicos.org, etc. Distribution map of the bamboo in Lombok was also produced from this study.

\section{RESULTS AND DISCUSSION}

\section{Results}

In this study, we recorded 11 species of bamboo found in Lombok Island: Bambusa glaucophylla, B. maculata, B. multiplex, B. spinosa, B. vulgaris, Dendrocalamus asper, Gigantochloa apus, G. atter, Schizostachyum brachycladum, S. lima, and Thyrsostachys siamensis.
Identification key to the bamboo species of Lombok

1 a. Branch complements with several sub-equal slender branches ...................................... 2

b. Branch complements with a dominant primary branch and several smaller branches ............... 3

2 a. Culm internodes more than $50 \mathrm{~cm}$ long, green; culmsheaths blade narrowly lanceolate and deflexed, auricles not prominent $(<1 \mathrm{~mm})$........ Schizostachyum lima

b. Culm internodes less than $50 \mathrm{~cm}$ long, bluish-green or golden-yellow with narrow green stripes; culmsheaths blade broadly triangular and erect, auricles prominent $(1 \mathrm{~cm})$... Schizostachyum brachycladum

3 a. Culm-sheaths covered with white hairs .............. Thyrsostachys siamensis

b. Culm-sheaths glabrous or covered with light brown to black hairs

4 a. Branches bearing spines.......... Bambusa spinosa

b. Branches without spines. ........................ 5

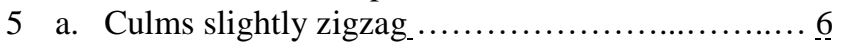

b. Culms relatively straight/erect ................. 9

6 a. Culm-sheaths glabrous; leaves usually at the end of a branch ...................... Bambusa multiplex

b. Culm-sheaths covered with light brown to black hairs; leaves spreading over the branch .......... 7

7 a. Culms up to $5 \mathrm{~m}$ high, $1.5-2.5 \mathrm{~cm}$ in diameter; leaves green with white stripes along the main nerve ......................... Bambusa glaucophylla

b. Culms 15-20 $\mathrm{m}$ high, 4-9 $\mathrm{cm}$ in diameter; leaves green without white stripes .................... 8

8 a. Young shoots green with yellow stripes on the sheath; culms green with yellow stripes when young, becoming green with brown spots when mature............................Bambusa maculata

b. Young shoots green or yellow; culms green with or without inflated internodes in the lower part or yellow with green stripes......... Bambusa vulgaris

9 a. Culms covered with wax when young; aerial root appears from the base to the upper part of the culm ............................. Dendrocalamus asper

b. Culms without covered with wax when young; aerial root appears only in the base part of the culm ..... 10 
10 a. Young shoots green; auricles of culm-sheaths rimlike, 1-3 mm high ................ Gigantochloa apus

b. Young shoots purplish green; auricles of culmsheaths rounded or rounded with curved outward, 3.5-7 mm high Gigantochloa atter

\section{Synopsis of bamboo in Lombok}

Bambusa glaucophylla Widjaja, Reinwardtia 11(2): 59 (1997). Type: Indonesia. Kedung Halang, Bogor, Java, E.A. Widjaja s.n. (holotype: BO!; Isotype K, L). Figure 2.A.

Description. Young shoots green. Culms up to $5 \mathrm{~m}$ high with erect tips, slightly zigzagged, green, glabrous when mature, internodes $20-25 \mathrm{~cm}$ long, $1.5-2.5 \mathrm{~cm}$ diameter. Branches grow near the ground with a dominant primary branch and several smaller branches, without spines. Culmsheaths deciduous, covered with brown to black hairs; auricles rounded and slightly curved outward, about $2 \mathrm{~mm}$ high, bristles 2-3 mm long; ligule entire, glabrous or slightly hairy; blade triangular and erect. Leaves 5-12 $\times 1$ $1.5 \mathrm{~cm}$, green with white stripes along the main nerve, glabrous; auricles rounded and curved outward, glabrous; ligule entire and glabrous.

Habitat and ecology. Cultivated in the home yard at an altitude of 15-90 m. Also found in wet or dry areas (Widjaja 2001a) in gardens, a city park (Widjaja 1997), and a riverbank (Huzaemah et al. 2016).

Distribution in Lombok. Southwest Praya, Central Lombok; Mataram (Widjaja 2001a); Gangga, North Lombok (Huzaemah et al. 2016) (Figure 3).

Vernacular names. Bambu putih (Indonesia) (Widjaja 2001a), santong hias (Sasak Bayan) (Huzaemah et al. 2016), bambu hias (Central Lombok).

Uses. This bamboo is used for hedges or as an ornamental plant.

Specimen examined. Indonesia: Lombok, Central Lombok District, Jongat Sub-distrik, Sukarana Village, 8'41'57.9” S, 116²'09.2” E, 30 November 2019 , I.P.G.P. Damayanto 1047 (BO).

Bambusa maculata Widjaja, Reinwardtia 11(2): 63 (1997). Type: Indonesia. Moluccas, Tongde Village, South Ternate, E.A. Widjaja 4881 (holotype: BO!; Isotype K, L, US). Figure 2.B.

Description. Young shoots green with yellow stripes. Culms up to $15 \mathrm{~m}$ high, slightly zigzagged, green with yellow stripes when young becoming green with brown spots when mature, internodes $30-35 \mathrm{~cm}$ long, $4-7 \mathrm{~cm}$ in diameter. Branches with a dominant primary branch and several smaller branches, without spines. Culm-sheaths persistent to deciduous, glabrous or covered with dark hairs; auricles rounded and curved outward, up to $5.5 \mathrm{~mm}$ high, bristles up to $15 \mathrm{~mm}$ long; ligule entire, glabrous; blade triangular, erect to spreading. Leaves-blades 22.5$37.5 \times 1-4.5 \mathrm{~cm}$, green, glabrous; auricles inconspicuous, glabrous; ligule denticulate, up to $1 \mathrm{~mm}$ high, glabrous.

Habitat and ecology. Cultivated in dry areas in lowlands (Widjaja 1997, 2001a, b) and around riverbanks (Putri et al.
2016; Munawarah et al. 2019) at an altitude of 20-340 m (Huzaemah et al. 2016; Mentari et al. 2018).

Distribution in Lombok. Mataram (Widjaja 2001a); Batukliang, Central Lombok (Peneng et al. 2005); Gangga, North Lombok (Huzaemah et al. 2016); Keruak, East Lombok (Mentari et al. 2018); Batu Layar (Putri et al. 2016) and Gunung Sari (Munawarah et al. 2019), West Lombok (Figure 3).

Vernacular names. Bambu tutul (Sasak Bayan) (Huzaemah et al. 2016) or treng borek (Batukliang) (Peneng et al. 2005).

Specimen examined. There was no specimen available, however, the evidence of the existence of this bamboo in Lombok can be seen in Huzaemah et al. (2016), Mentari et al. (2018) and Munawarah et al. (2019).

Bambusa multiplex (Lour.) Raeusch. ex Schult.f., Syst. Veg. 7(2): 1350 (1830). Type: Vietnam. Anon. s.n. (holotype P). Figure 2.C.

Description. Young shoots green and glabrous. Culms up to $7 \mathrm{~m}$ high with arching tips, slightly zigzagged, green or yellow, internodes $30-50 \mathrm{~cm}$ long, $1-2.5 \mathrm{~cm}$ in diameter. Branches grow near the ground with sub-equal several branches and a dominant primary branch hardly prominent, without spines. Culm-sheaths deciduous and glabrous; auricles rim-like or inconspicuous with bristles up to $3 \mathrm{~mm}$ long; ligule irregularly toothed and glabrous; blade triangular and erect. Leaves-blades $5-12 \times 0.5-1.5 \mathrm{~cm}$, usually at the end of a branch, green, slightly hairy on the lower surface; auricles small, bristles up to $5 \mathrm{~mm}$ long; ligule irregularly toothed.

Habitat and ecology. Grows along the riverbank (Huzaemah et al. 2016; Putri et al. 2016), near roads and cultivated in cities at an altitude of $15-335 \mathrm{~m}$.

Distribution in Lombok. Mataram City; Kuta and Praya, Central Lombok (Peneng et al. 2005); Gangga, North Lombok (Huzaemah et al. 2016); Batu Layar, West Lombok (Putri et al. 2016) (Figure 3).

Vernacular names. Treng cina (Peneng et al. 2005), santong hias cina (Sasak Bayan) (Huzaemah et al. 2016), bambu cina (Indonesia) (Widjaja 2001a, b), or bambu hias (Mataram).

Specimens examined. Indonesia: Lombok, along the road from Kuta to Mataram, 851'22.5” S, 116 $111^{\prime} 05.5^{\prime \prime} \mathrm{E}$, 20 February 2005, H. Tobe \& N. Utami Tobe1251 (BO); Lombok, Mataram City, Ampenan Sub-distrik, Dayan Peken, Near Ampenan River, 8³4'22.3”' S, 11604’41.8” E, 30 November 2019, I.P.G.P. Damayanto 1053 (BO).

Bambusa spinosa Roxb., Hort. Bengal.: 25 (1814). Type: India (probably). Roxburgh s.n. (BM). Figure 2.D.

Description. Young shoots yellowish-green, covered with scattered black hairs, sometimes green with yellow stripes in the culm-sheath. Culms up to $25 \mathrm{~m}$ high, slightly zigzagged, green, internodes $25-30 \mathrm{~cm}$ long, $5-10 \mathrm{~cm}$ in diameter. Branches grow near the ground with a dominant primary branch and several smaller branches, bearing stout straight or curved spines. Culm-sheaths deciduous; auricles on either side of the base of the blade, up to $5 \mathrm{~mm}$ high, bristles up to $25 \mathrm{~mm}$ long; ligule up to $3 \mathrm{~mm}$ high with 
bristles in the outer parts; blade narrowly lanceolate, erect in basal and apical sheaths, spreading to deflexed in middle sheaths. Leaves-blades 15-20 × 1.5-2 cm, green; auricles small with few bristles about $3 \mathrm{~mm}$ long; ligule truncates with short bristles.

Habitat and ecology. Grows in wet and dry areas (Widjaja 2001a) and in a Mt. Tunak Nature Tourism Park at an altitude of $15-20 \mathrm{~m}$.
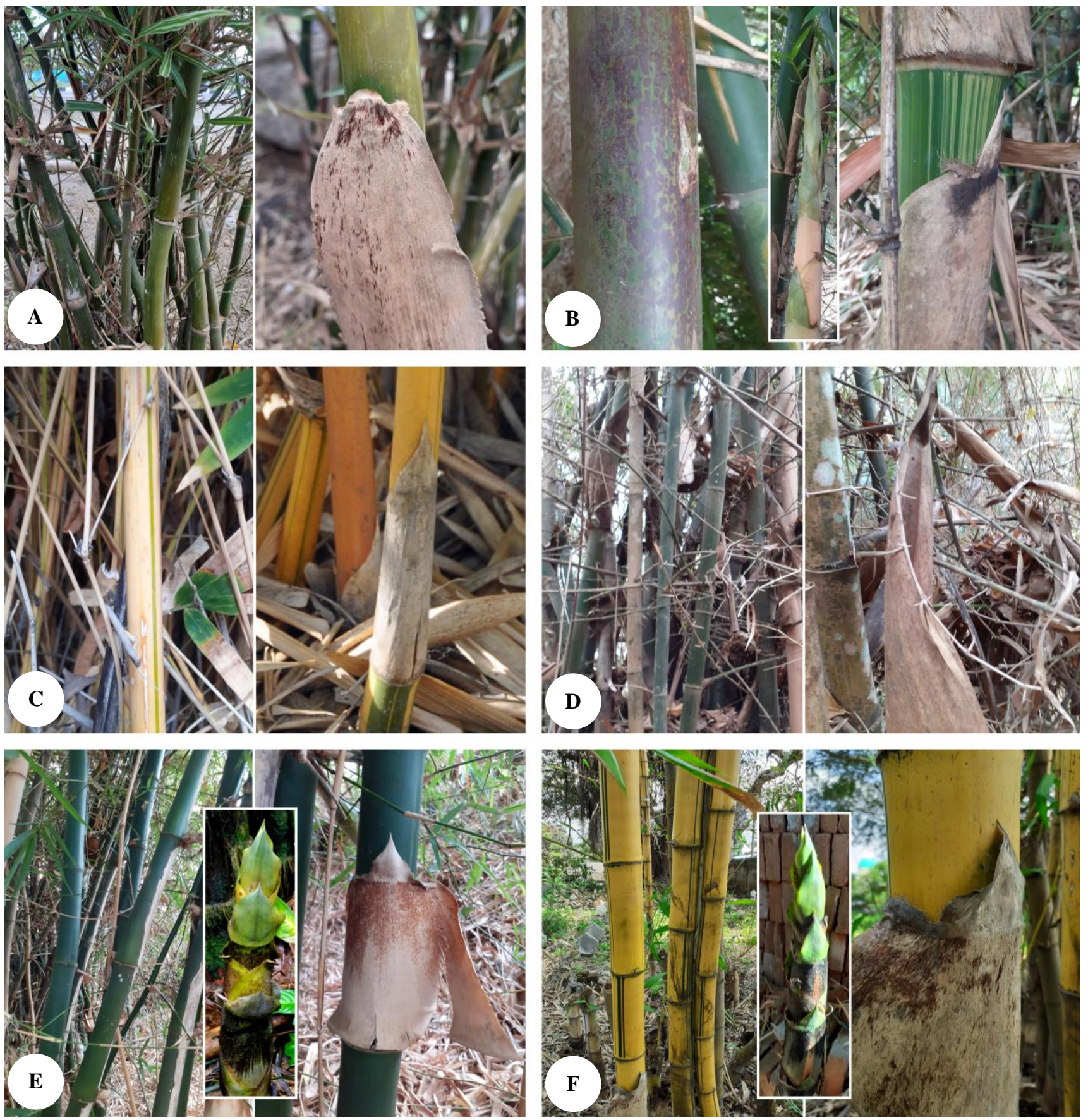

Figure 2. Culms (left), culm-sheaths (right) and young shots (inset) of Bambusa glaucophylla (A), B. maculata (B), B. multiplex (C), B. spinosa $(\mathrm{D})$, B. vulgaris var. vulgaris $(\mathrm{E})$ and $B$. vulgaris var. striata $(\mathrm{F})$
Distribution in Lombok. The western part of Lombok (Widjaja 2001a); Pujut, Central Lombok. This species was also seen in Lembar around Marije Village, West Lombok (Figure 3).

Vernacular names. Treng greng (Pujut) (Peneng et al. 2005) or bambu duri (West Lombok).

Specimen examined. Indonesia: Central Lombok, Pujut Sub-distrik, Mt. Tunak Nature Tourism Park, 8 March 2018, H. Rustiami 2220 (BO). 


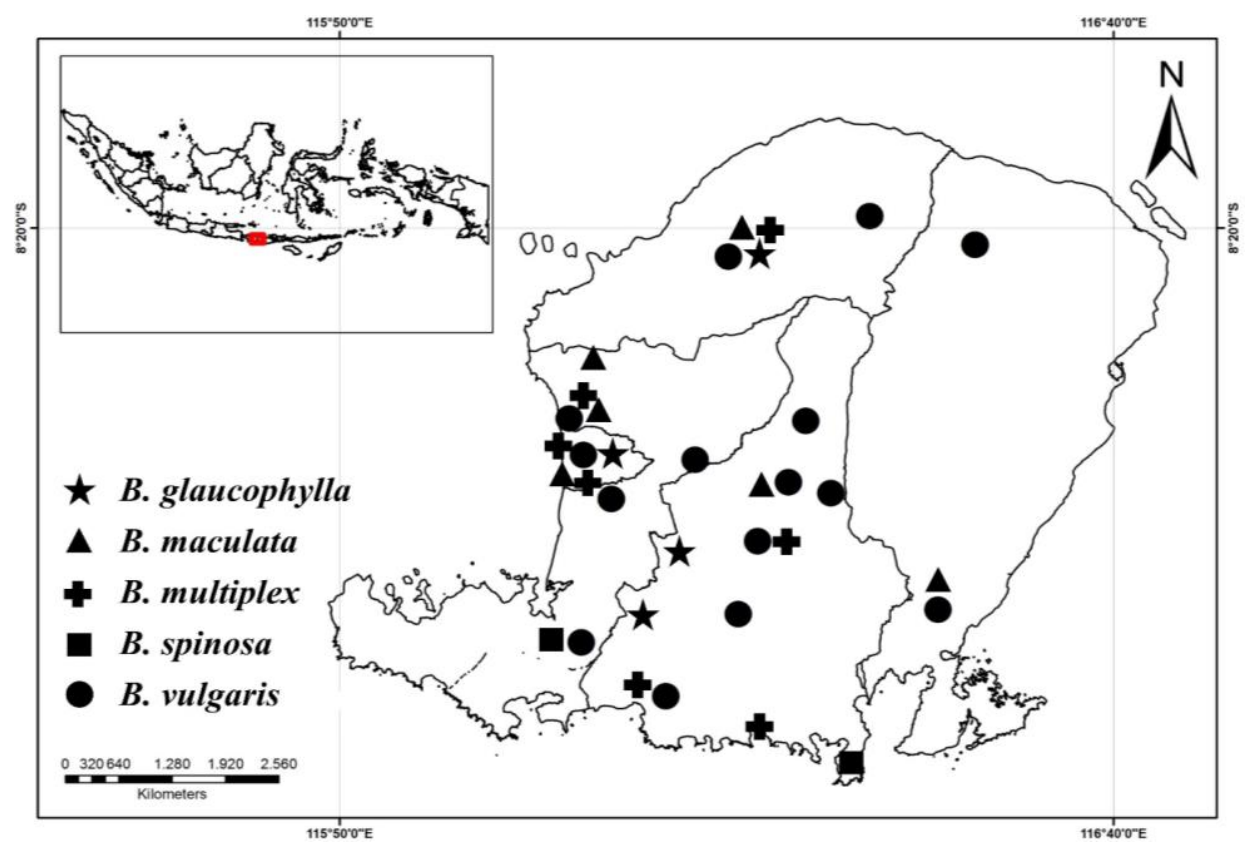

Figure 3. Distribution of Bambusa glaucophylla, B. maculata, B. multiplex, B. spinosa and B. vulgaris in Lombok, West Nusa Tenggara, Indonesia

Bambusa vulgaris Schrad. ex Wendl., Coll. Pl. 2: 26 (1808). Type: India. "Bambusa vulgaris Wend.", ex herb. Wendland Nos. 13986-13989 (GOET!). Figure 2.E-F.

Description. Young shoots green or yellow, covered with brown to black hairs. Culms up to $20 \mathrm{~m}$ high, slightly zigzagged, green with or without inflated internodes in the lower part or yellow with green stripes, internodes 20-30 $\mathrm{cm}$ long, 6-9 $\mathrm{cm}$ in diameter. Branches with a dominant primary branch and several smaller branches, without spines. Culm-sheaths deciduous, covered with dark brown to black hairs; auricles rounded and curved outward, up to $10 \mathrm{~mm}$ high, bristles up to $7 \mathrm{~mm}$ long; ligule toothed, up to $3 \mathrm{~mm}$ high with short bristles; blade broadly triangular and erect. Leaves-blades $8-32 \times 1-4 \mathrm{~cm}$, green; auricles small with few bristles about $2 \mathrm{~mm}$ long; ligule entire or subentire.

Habitat and ecology. This bamboo grows in the forest (Rini et al. 2017), along the riverbank (Putri et al. 2016; Mentari et al. 2018), the roadside and cultivated in villages at an altitude of $15-1100 \mathrm{~m}$.

Distribution in Lombok. Bayan (Rini et al. 2017) and Gangga (Huzaemah et al. 2016), North Lombok; Batu Layar (Putri et al. 2016) and Narmada (Peneng et al. 2005), West Lombok; Keruak (Mentari et al. 2018) and Sembalun, East Lombok; Praya, North Batukliang (Peneng et al. 2005), Kopang and Pujut, Central Lombok (Figure 3).

Vernacular names. Aur (Sasak Bayan) or aur kuning (Sasak Bayan) (Huzaemah et al. 2016), treng aur gading (North Batukliang) or treng aur hijau (North Batukliang) (Peneng et al. 2005), bambu kuning or bambu ampel (Bayan) (Rini et al. 2017), aur ketu (East Lombok), tereng tali, tereng aur and tereng galah (Central Lombok).

Specimens examined. Indonesia: Lombok, Kopang, 14 June 1964, Sun Hong-Fan 9092 (BO); East Lombok,
Sembalun Sub-distrik, Sembalun Village, 8²1'7.27” S, 116 31'5.07' E, 22 August 2000, R. Mulyati, Rugayah, Pratiwi, \& Hamzah 606 (BO); Lombok, Kuta, along the the road from Kuta to Mataram, 8 $8^{\circ} 1^{\prime} 22.5^{\prime}$ ' S, 116 $16^{\circ}$ '05.5” E, 20 February 2005, H. Tobe \& N. Utami Tobe1250 (BO); Central Lombok, Pujut Sub-distrik, Mertak Village, "tereng tali", 13 March 2018, H. Rustiami s.n. (BO); Central Lombok, Pujut Sub-distrik, Mertak Village, "tereng aur", 13 March 2018, H. Rustiami s.n. (BO); Central Lombok, Pujut Sub-distrik, Mertak Village, "tereng galah", 13 March 2018, H. Rustiami s.n. (BO); Central Lombok, Pujut Sub-distrik, Tanak Awu Village, 8०45'52.4” S, 116¹5'46.7” E, 30 November 2019, I.P.G.P. Damayanto 1044 (BO); West Lombok, Labu Api Sub-distrik, Bagik Polak Village, $8^{\circ} 38^{\prime}$ 08.7” S, $116^{\circ} 07^{\prime} 34.6$ " E, 30 November 2019, I.P.G.P. Damayanto 1051 (BO).

Notes. There are two varieties of this bamboo in Lombok, B. vulgaris var. vulgaris (Figure 2.E) and var. striata (=vitata) (Figure 2.F). In Indonesia, there are three varieties of $B$. vulgaris, var. vulgaris (green culm), var. striata (yellow culm with green stripes) and var. wamin (green culm with inflated internodes) (Widjaja 2001b).

Dendrocalamus asper (Schult.f.) Backer ex Heyne, Nutt. P1. Ned.-Ind. 2(1): 301 (1927). Type: Unknown [Based on Syst. Veg. 7(2): (1830) (as Bambusa aspera Schult.f.) was noted "In Amboina et Huamchela ad montium pedes"). Figure 4.A.

Description. Young shoots purplish-black, covered with velvety brown to black hairs. Culms up to $30 \mathrm{~m}$ high, erect, green, dark green, purplish-green or greyish-green, when young covered with velvety golden-brown appressed hairs, later glabrous, internodes $35-50 \mathrm{~cm}$ long, $12-15 \mathrm{~cm}$ in 
diameter, aerial root appears from the base to the upper part of the culm. Branches grow about 1.5-3 m from the ground with a dominant primary branch and several smaller branches, without spines. Culm-sheaths deciduous and covered with velvety dark brown to black hairs; auricles prominent and sometimes crimped, up to $8 \mathrm{~mm}$ high, bristles up to $4 \mathrm{~mm}$ long; ligule irregularly toothed, up to 9 $\mathrm{mm}$ high with short bristles; blade lanceolate, erect first and later deflexed. Leaves-blades 20-30 × 2-4 cm, green; auricles small or absent and glabrous; ligule entire and very short.

Habitat and ecology. Grows in the garden, along with the riverbank (Putri et al. 2016; Munawarah et al. 2019) and the forest (Rini et al. 2017; Rini 2018) at an altitude of 212-1100 m.

Distribution in Lombok. Gangga (Huzaemah et al. 2016) and Bayan (Rini et al. 2017; Rini 2018), North Lombok; Batukliang, Central Lombok (Peneng et al. 2005); Batu Layar (Putri et al. 2016) and Gunung Sari (Munawarah et al. 2019), West Lombok; Sembalun and Sikur, East Lombok (Figure 5).

Vernacular names. Treng petung (Sikur) (Rini et al. 2017), pring galah (East Lombok) or petung (East Lombok).

Specimens examined. Indonesia: East Lombok, Sembalun Sub-distrik, Sembalun Village, 8²1'7.27' S, 116³1'5.07" E, 22 August 2000, R. Mulyati, Rugayah, Pratiwi, \& Hamzah 605 (BO); East Lombok, Sikur Subdistrik, Kembang Kuning Village, 8³1'57.9” S, $116^{\circ} 25^{\prime} 30.6$ " E, 2 December 2019, I.P.G.P. Damayanto 1057 (BO).

Gigantochloa apus (Schult.f.) Kurz, Nat. Tijdschr. Ned. Ind. 27: 226 (1864). Type: Indonesia. Java, G. Salak, Blume s.n. (holotype M; isotype L). Figure 4.B.

Description. Young shoots green, covered with brown and black hairs. Culms up to $30 \mathrm{~m}$ high, erect, greyishgreen to bright or yellowish-green, covered with white wax when young, shiny, glabrous, internodes 30-70 cm long, 6$14 \mathrm{~cm}$ in diameter, aerial root appears only in the base part of the culm. Branches usually grow upper half from the ground with a dominant primary branch and several smaller branches, without spines. Culm-sheaths not easily fall, green and covered with dark brown to black hairs when young, turning yellow-brown and glabrous when mature; auricles rim-like, up to $3 \mathrm{~mm}$ high, bristles $6-7 \mathrm{~mm}$ long; ligule toothed, up to $4 \mathrm{~mm}$ high, glabrous; blade ovatetriangular, spreading to deflexed. Leaves-blades 15-40 $\times 2$ $9 \mathrm{~cm}$, green; auricles small, rounded and glabrous; ligule up to $4 \mathrm{~mm}$ high, entire and glabrous.

Habitat and ecology. Grows in the forest (Rini et al. 2017) and along the riverbank (Huzaemah et al. 2016; Putri et al. 2016; Mentari et al. 2018; Munawarah et al. 2019) at an altitude of 15-1100 m.

Distribution in Lombok. Bayan (Rini et al. 2017) and Gangga (Huzaemah et al. 2016), North Lombok; Mantang (Peneng et al. 2005) and Kuripan, Central Lombok; Batu Layar (Putri et al. 2016) and Gunung Sari (Munawarah et al. 2019), West Lombok; Keruak (Mentari et al. 2018) and Sembalun, East Lombok (Figure 5).
Vernacular names. Treng tali (Kuripan), bambu tali (Bayan) (Rini et al. 2017), or pring tali (Sembalun).

Specimens examined. Indonesia: East Lombok, Sembalun Sub-distrik, Sembalun Village, 8²1'7.27” S, 116³1'5.07" E, 22 August 2000, R. Mulyati, Rugayah, Pratiwi, \& Hamzah 607 (BO); West Lombok, Kuripan Sub-distrik, Kuripan Village, 840'21.1" S, 116¹0'16.9” E, 30 November 2019, I.P.G.P. Damayanto 1049 (BO).

Gigantochloa atter (Hassk.) Kurz, Nat. Tijdschr. Ned. Ind. 27: 226 (1864). Type: Indonesia. Java, Kurz s.n. (neotype K!). Figure 4.C.

Description. Young shoots green or purplish-green, covered with black hairs. Culms up to $25 \mathrm{~m}$ high, erect, bluish-green to dark green with distinct pale rings on the nodes, covered with scattered black hairs when young, becoming glabrous when mature, internodes $30-50 \mathrm{~cm}$ long, 6-11 cm in diameter, aerial root appears only in the base part of the culm. Branches with a dominant primary branch and several smaller branches, without spines. Culmsheaths deciduous, covered with black hairs; auricles rounded or rounded with curved outward, up to $6 \mathrm{~mm}$ high, bristles 6-7 $\mathrm{mm}$ long; ligule toothed, up to $6 \mathrm{~mm}$ high and glabrous; blade lanceolate, deciduous and deflexed. Leaves-blades 15-40 × 3-6 cm, green; auricles small, up to $1 \mathrm{~mm}$ high and glabrous; ligule entire, up to $1 \mathrm{~mm}$ high and glabrous.

Habitat and ecology. Grows in the forest (Rini et al. 2017), along riverbanks (Huzaemah et al. 2016; Putri et al. 2016; Mentari et al. 2018; Munawarah et al. 2019), roadsides (Mentari et al. 2018) and cultivated in villages at an altitude of 15-756 m.

Distribution in Lombok. Gangga, North Lombok (Huzaemah et al. 2016); Keruak, (Mentari et al. 2018) and Masbagik, East Lombok; Batu Layar (Putri et al. 2016) and Gunung Sari (Munawarah et al. 2019), West Lombok; North Batukliang (Peneng et al. 2005), Kuta, Jongat, and Southwest Praya, Central Lombok (Figure 5).

Vernacular names. Santong biasa (Sasak Bayan) (Huzaemah et al. 2016), bambu santong (Rini et al. 2017), treng galah (North Batukliang) (Peneng et al. 2005; Munawarah et al. 2019) and tereng gerang (Lombok Tengah).

Specimens examined. Indonesia: Central Lombok, Kuta, along the road from Kuta to Mataram, 8 $8^{\circ} 1^{\prime} 22.5^{\prime \prime} \mathrm{S}$, $116^{\circ} 11^{\prime} 05.5$ " E, 20 February 2005, H. Tobe \& N. Utami Tobe1249 (BO); Central Lombok, Pujut Sub-distrik, Mertak Village, "tereng gerang", 13 March 2018, $H$. Rustiami s.n. (BO); Central Lombok, Southwest Praya Subdistrik, Batubolong Village, 842’41.4” S, 116 12 '50.0” E, 30 November 2019, I.P.G.P. Damayanto 1045 (BO); Central Lombok, Jongat Sub-distrik, Sukarana Village, 841'57.9” S, 116²'09.2” E, 30 November 2019, I.P.G.P. Damayanto 1047 (BO); East Lombok, Masbagik Sub-distrik, Paokmontong Village, Dasan Malang SubVillage, 28 November 2019, S. Sunarti \& M. Rahayau 833 (BO).

Schizostachyum brachycladum (Kurz ex Munro) Kurz, J. Asiat. Soc. Bengal. Pt. 2, Nat. Hist. 39: 89 (1870). 
Type: Indonesia. Buitenzorg (now Bogor), Java, Anon. s.n. (Syntype K!). Figure 4.D.

Description. Young shoots yellowish-green or yellow, covered with brown hairs. Culms up to $12 \mathrm{~m}$ high, erect, green or yellow with green stripes, internodes $30-50 \mathrm{~cm}$ long, $5-10 \mathrm{~cm}$ in diameter. Branches with several sub-equal slender branches, without spines. Culm-sheaths 17-18 $\times$ 17-18 cm, covered with light brown to brown hairs; auricles small up to $1 \mathrm{~cm}$ high, bristles up to $5 \mathrm{~mm}$ long; ligule entire, up to $2 \mathrm{~mm}$ high and glabrous; blade $4-5 \times 4$ $5.5 \mathrm{~cm}$, broadly triangular, erect. Leaves-blades $20-35 \times 4$ $6 \mathrm{~cm}$ wide, green; auricles small, less than $1 \mathrm{~mm}$ high, bristles up to $8 \mathrm{~mm}$ long; ligule entire, up to $1 \mathrm{~mm}$ high and glabrous.

Habitat and ecology. Cultivated in the city and found in riverbanks at an altitude of 15-316 m (Munawarah et al. 2019).

Distribution in Lombok. West Lombok (Peneng et al. 2005; Munawarah et al. 2019), Central Lombok, and Mataram (Figure 5). This bamboo is widespread in Lombok.

Vernacular names. Treng gading, tereng kuning (green culm) or tereng aur (yellow culm) (Sasak) (Munawarah et al. 2019), bambu lemang (green culm) and bambu gading (yellow culm).

Specimen examined. Indonesia: Central Lombok, Southwest Praya Sub-distrik, Batubolong Village, 8०42'41.4” S, 116 12'50.0” E, 30 November 2019, I.P.G.P. Damayanto 1046 (BO).

Notes. Widjaja et al. (2005) mentioned that $S$. brachycladum has two "varieties", with either a green culm or yellow culm with green stripes. The latter is found in Lombok as ornamental plant and is cultivated in cities.

Schizostachyum lima (Blanco) Merr., Amer. J. Bot. 3: 62 (1916). Type: Unknown (probably Philippines). Figure 4.E.

Description. Young shoots green, covered with brown hair. Culms up to $10 \mathrm{~m}$ high, erect, green internodes 50-120 $\mathrm{cm}$ long, 3-4 cm in diameter. Branches with several subequal slender branches, without spines. Culm-sheaths 17$18 \times 7-8 \mathrm{~cm}$, covered with brown to dark brown hairs; auricles not prominent, bristles up to $7 \mathrm{~mm}$ long; ligule short with bristles; blade $10-23 \times 5-10 \mathrm{~cm}$, narrowly lanceolate, deflexed. Leaves-blades 20-30 × 4-7 cm wide, green; auricles small, less than $1 \mathrm{~mm}$ high, bristles up to 8 $\mathrm{mm}$ long; ligule irregularly toothed, up to $1 \mathrm{~mm}$ high.

Habitat and ecology. Cultivated in villages up to $500 \mathrm{~m}$ asl. This bamboo is rare and only found in cultivation.

Distribution in Lombok. Kompang, Central Lombok (Figure 5).

Vernacular names. Treng buluh (Kompang).

Specimen examined. Indonesia: Central Lombok, Kompang Sub-distrik, Wajagesang Village, Dasan Baru Sub-Village, 8०36’00.5" S, $116^{\circ} 22^{\prime} 11.5^{\prime}$ E, 3 December 2019, I.P.G.P. Damayanto 1060 (BO).

Thyrsostachys siamensis Gamble, Ann. Roy. Bot. Gard. (Calcutta) 7: 59 (1896). Type: Thailand. Kurz s.n. (lectotype K!). Figure 4.F.
Description. Young shoots pale green to purplish-green, glabrous. Culms up to $10 \mathrm{~m}$ high, erect, pale green to greyish green, covered with persistent old culm-sheaths, internodes 10-30 cm long, 2-7 cm in diameter. Branches grow from mid-culm nodes upwards with a dominant primary branch and several smaller branches, without spines. Culm-sheaths persistent, covered with white hairs; auricles inconspicuous or very small; ligule entire and glabrous; blade narrowly triangular and erect. Leavesblades 7-14 cm $\times 5-8 \mathrm{~mm}$, pale green; auricles very small or not seen and glabrous; ligule entire and glabrous.

Habitat and ecology. Grows along the riverbank at an altitude of 14-167 m (Mentari et al. 2018; Munawarah et al. 2019) and cultivated in cities.

Distribution in Lombok. Gangga, North Lombok (Huzaemah et al. 2016); Keruak, East Lombok (Mentari et al. 2018); Batu Layar (Putri et al. 2016) and Gunung Sari (Munawarah et al. 2019), West Lombok; Mataram City (Figure 5). This bamboo is widespread across Lombok.

Vernacular names. Santong hias cina (Sasak Bayan) (Huzaemah et al. 2016) or tereng cina (Sasak Batu Penyu) (Munawarah et al. 2019) or treng jakarta.

Specimens examined. Indonesia: West Lombok, Gerung Sub-distrik, Beleke Village, 8³9'35.5” S, $116^{\circ} 07^{\prime} 50.6$ " E, 30 November 2019, I.P.G.P. Damayanto 1050 (BO); West Lombok, Gerung Sub-distrik, Beleke Village, 8³9'35.5” S, 11607'50.6” E, 30 November 2019, I.P.G.P. Damayanto 1050 (BO); Mataram City, Cakranegara Sub-distrik, West Cakranegara, Lingkungan Jeruk Manis, 8`35'04.8” S, 11607'30.8” E, 30 November 2019, I.P.G.P. Damayanto 1052 (BO).

\section{Doubtful species}

Bambusa albustiata and Bambusa ventricosa McClure

Bambusa albustiata mentioned by Peneng et al. (2005) was never reported as a species name of bamboo (see Vorontsova et al. 2016; ipni.org). Peneng et al. (2005) also suggested $B$. ventricosa was found in Lombok Tengah. This bamboo was reported from China to Vietnam (Vorontsova et al. 2016) and it has never been reported from Indonesia (Widjaja 2019). There were no descriptions available, no specimens, and no photographs of these bamboos. These bamboos are therefore not included in this paper.

\section{Dinochloa sp.}

Santi et al. (2019) reported Dinochloa sp. found in Lombok. Unfortunately, they did not provide a description of the species. Dinochloa has never been reported previously in Lombok. There was not enough evidence to include this bamboo in this paper.

\section{Guadua angustifolia Kunth}

Putri et al. (2016) reported Guadua angustifolia found in Meninting River, West Lombok. Guadua angustifolia originated from South America (Judziewicz et al. 1999). Londono (2001) mentioned this bamboo had been introduced to Indonesia and cultivated in Java and Bali (Widjaja 2019). The description of ' $G d$. angustifolia' in Putri et al. (2016), however, was incomplete. The important 
morphological characters to identify this bamboo in the photograph of Putri et al. (2016) was also not clear and there was no specimen mentioned. We also did not found this bamboo during our fieldwork around Meninting River, West Lombok.

Although we do not include the $G d$. angustifolia in this paper, we found information that plantlets of $G d$. angustifolia from tissue culture have been traded in Indonesian online stores (see TBNV 2018). Guadua angustifolia has been listed on a list of bamboo species sold by a bamboo tissue culture company, PT. Bambu Nusa Verde, located in Yogyakarta, Java (see BNV 2019). Based on personal communication with the staff of PT. Bambu Nusa Verde (Mrs Hana), Gd. angustifolia has been exported to other countries and only occasionally purchased locally, including in Bali and Lombok. This increases the chances that $G d$. angustifolia is found on Lombok-this however needs confirmation.
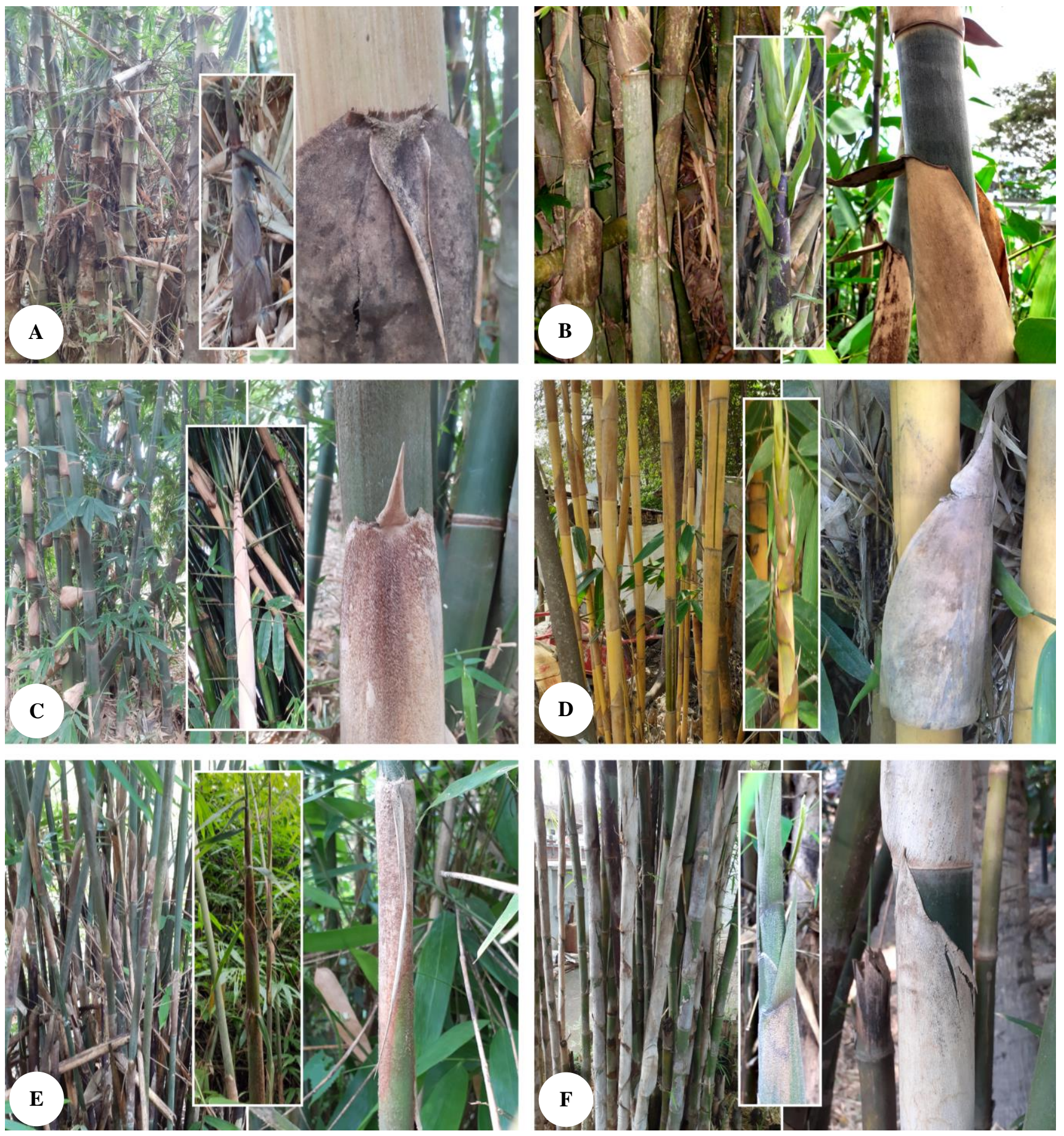

Figure 4. Culms (left), culm-sheaths (right) and young shoots (inset) of Dendrocalamus asper (A), Gigantochloa apus (B), G. atter (C), Schizostachyum brachycladum (D), S. lima (E) and Thyrsostachys siamensis (F) 


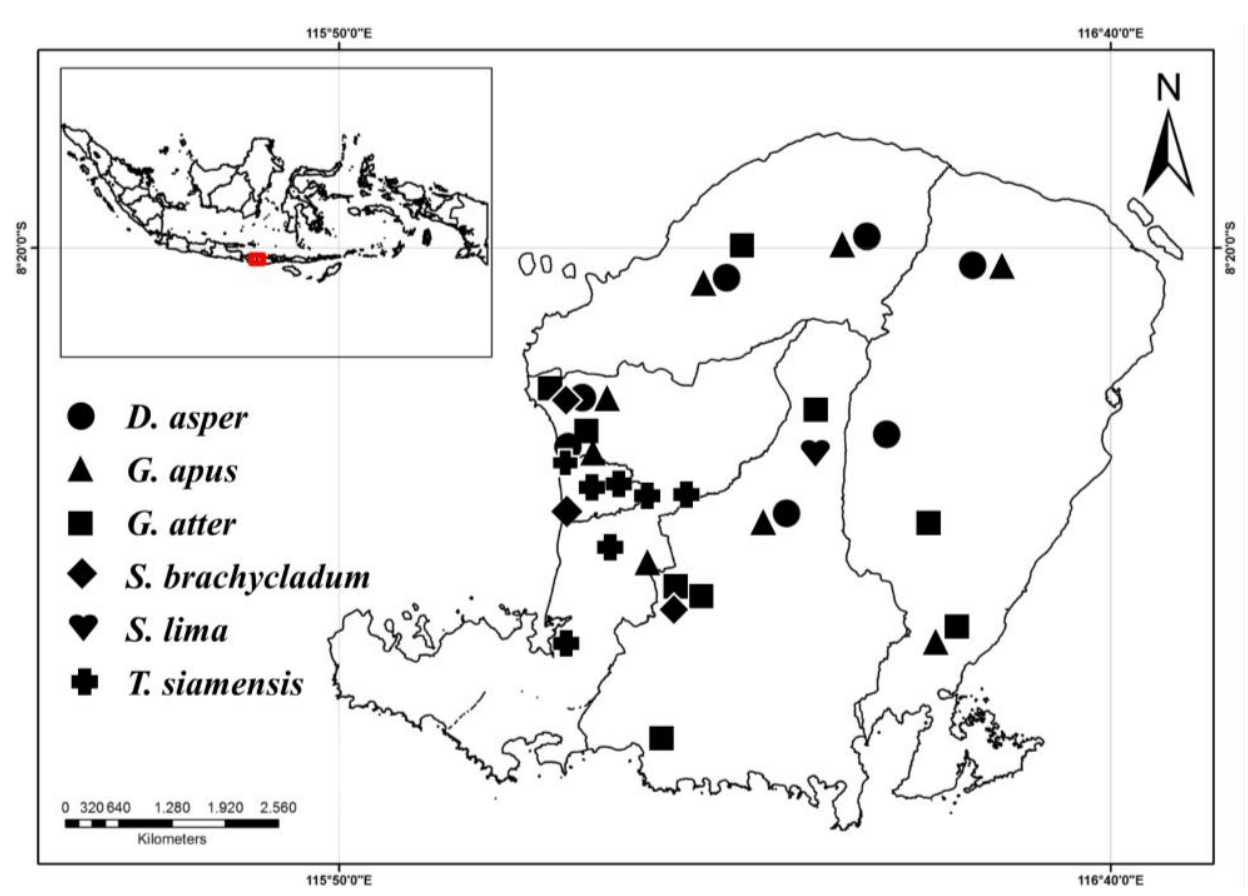

Figure 5. Distribution of Dendrocalamus asper, Gigantochloa apus, G. atter, Schizostachyum brachycladum, S. lima and Thyrsostachys siamensis in Lombok, West Nusa Tenggara, Indonesia

\section{Schizostachyum jaculans Holttum}

Schizostachyum jaculans was reported from Lombok by Huzaemah et al. (2016), Putri et al. (2016) and Santi et al. (2019). This bamboo, however, is from Peninsular Malaysia (Dransfield 1995). Holttum (1953) reported that $S$. jaculans has a culm with $3.5 \mathrm{~cm}$ in diameter, culmsheath auricles absent and replaced by long bristles and ligule of leaf-sheath small and glabrous. This is different from 'S. jaculans' described by Huzaemah et al. (2016), Putri et al. (2016), and Santi et al. (2019). Based on the photographs of this bamboo in Lombok, it is very similar to S. lima or S. silicatum Widjaja. We did not find S. jaculans during our fieldwork. Therefore, this bamboo is not included in this paper.

Pseudosasa japonica (Siebold \& Zucc. ex Steud.) Makino ex Nakai

Rizkillah (2018) reported that $P$. japonica occurred in Senggigi, West Lombok. This bamboo is common in Korea and Japan (Vorontsova et al. 2016) and has never been reported from Lombok previously. Vorontsova et al. (2016) and Ariati et al. (2019) reported that $P$. japonica was introduced in Java, although Widjaja (2001b, 2019) never mentioned this species in Java. Only P. amabilis (McClure) Keng f. has been introduced to Cibodas Botanic Garden, Java (Widjaja 2001b; Widyatmoko et al. 2010) and also Bali 'Eka Karya' Botanic Garden, Bali (Widjaja 2019). A photograph and a description of $P$. japonica from Rizkillah (2018) clearly showed that it is Thyrsostachys siamensis.

\section{Discussion}

There are 176 species and 24 genera of bamboo in Indonesia (Widjaja 2019). Of those, only about 6\% (11) of species and $21 \%$ (5) of genera were found in Lombok based on the results of this study. The diversity of bamboo in Lombok is still relatively low compared with some regions in Indonesia (Figure 6). Bamboos in Lombok reach $58 \%$ (11) of the total bamboo species in Lesser Sunda Islands (LSI) (19 species). There are no endemic bamboo species in Lombok. This may be because Lombok is not as large as the other Indonesian islands (Figure 6).

Bamboo diversity in Lombok is higher (11 species) than other Indonesian small islands (eight to nine species) (Figure 7). For example, Peleng Island in Central Sulawesi which covers almost half the area of Lombok (see Hasanah 2017; BPSPNTB 2018) is reported to have eight species and six genera of bamboos (Damayanto and Rahmawati 2020), even Bengkalis Island in Riau with an area of only 8.5\% of Lombok (see BPSKB 2018; BPSPNTB 2018) is reported to have nine species and five genera of bamboos (Rijaya and Fitmawati 2019).

Lowland regions with warmer temperatures and high rainfall usually have high species richness (Sinauer 2010). Bamboo diversity in several islands in Indonesia does not appear to be limited by rainfall (Figure 7). For instance, Lombok has a higher number of bamboo species than Selayar Islands, South Sulawesi, although annual rainfall in Lombok is about 33\% lower than Selayar (BPS 2017; Liana et al. 2017). This is likely because bamboo is found in a wide range of habitats from dry to humid areas, swamps, marginal land, dry or regularly flooded riverbanks (Dransfield and Widjaja 1995), and from lowlands up to highlands up to $4300 \mathrm{~m}$ asl (Clark 2006). Rainfall is therefore unlikely to limit Bamboo species richness. 


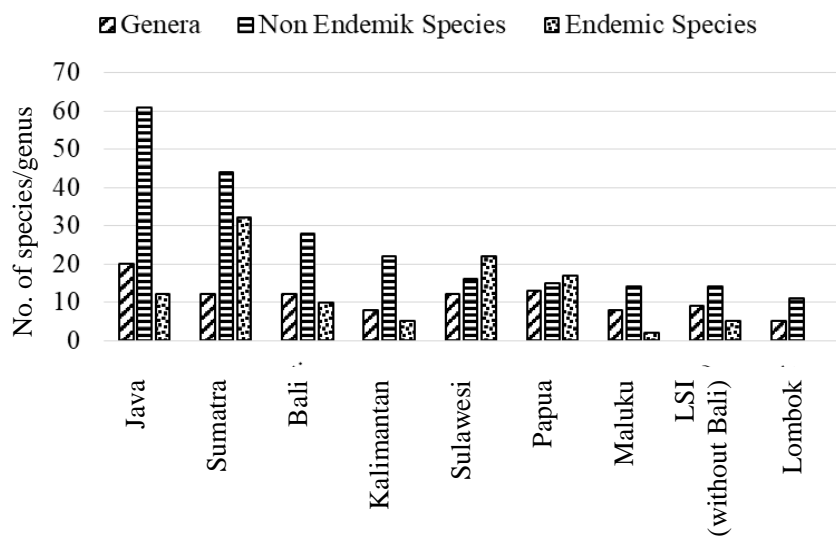

Figure 6. Comparison of bamboo diversity in several areas in Indonesia [processed from Widjaja (2019) and research data]

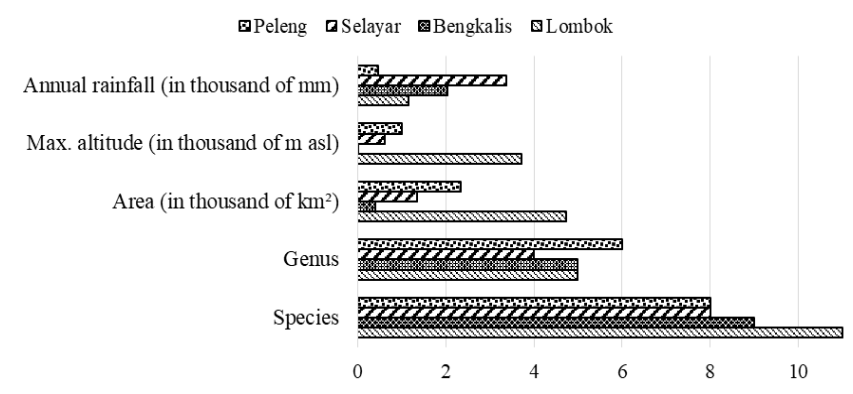

Figure 7. Comparison of bamboo diversity and ecological conditions in some small islands in Indonesia [processed from BPS (2017), Hasanah (2017), Liana et al. (2017), BPSKB (2018), BPSKKS (2018), BPSPNTB (2018), Rijaya and Fitmawati (2019), Damayanto and Rahmawati (2020) and research data]

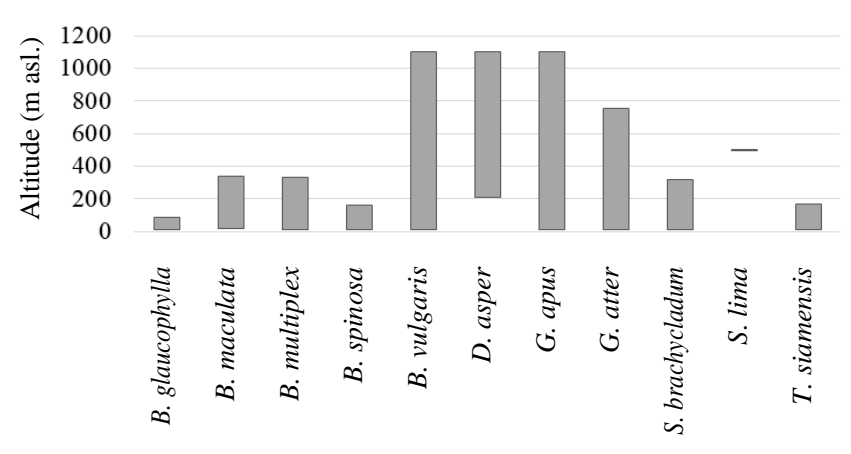

Figure 8. Elevation range of bamboo species in Lombok, West Nusa Tenggara, Indonesia

Some species of bamboos in Lombok were found growing in a fairly wide range of altitudes (Figure 8), such as B. vulgaris, D. asper, G. apus, and G. atter. These bamboos are also widespread in Lombok (see Figures 3 and 5). They were commonly found in lowland and highland and were reported from almost all regions of Indonesia (Widjaja 2019). Meanwhile, S. lima was only found at an altitude of about $500 \mathrm{~m}$ (Figure 8). Based on the interviews with residents in Lombok, S. lima was rarely found and it was rarely collected in our exploration. There is no information about $S$. lima reported before in Lombok, except a report of Rini et al. (2017) who mentioned that $S$. lima (locally known as bambu bilis) can be found in Senaru Forest, North Lombok. They, unfortunately, did not provide a complete description and the photos presented were also not very clear.

Other species, such as B. glaucophylla, B. multiplex, $S$. brachycladum and $T$. siamensis are ornamental bamboo (Widjaja 2001b), so distributions are mostly in urban areas which are usually located in the lowlands of Lombok. On the other hand, B. spinosa is found in the dry areas of southern Lombok which is coastal lowland.

It can be concluded that there are 11 species of bamboos (Bambusa glaucophylla, B. maculata, B. multiplex, B. spinosa, B. vulgaris, Dendrocalamus asper, Gigantochloa apus, G. atter, Schizostachyum brachycladum, S. lima, and Thyrsostachys siamensis) in Lombok, Indonesia. Bambusa vulgaris is the most widespread bamboo, while S. lima is rare.

\section{ACKNOWLEDGEMENTS}

The curator of Herbarium Bogoriense (BO), Research Center for Biology, Indonesian Institute of Sciences (LIPI) is acknowledged for the permission given to access the herbarium specimens. Thanks go to Ruslan 'Ucang' (librarian of Research Center for Biology, LIPI) for help finding references. Sincere thanks go to Tri Mulyaningsih and Evy Aryanti (Mataram University), Ni Made Meila Anggarawati, Ridwan, Iwan, M. A. Rizkillah and Ayu (colleagues in Mataram), Dewi Susan and Yasper Michael Mambrasar (BO), and Hana (Bambu Nusa Verde) for valuable information, Dita Ervianti for helping us to prepare the map, Rani Asmarayani (BO) and Liam A. Trethowan (K) for help on the English.

\section{REFERENCES}

Ariati SR, Astuti RS, Supriyatna I, Yuswandi AY, Setiawan A, Saftaningsih D, Pribadi DO. 2019. An Alphabetical List of Plant Species Cultivated in the Bogor Botanic Gardens. Center for Plant Conservation, Bogor Botanic Gardens, Bogor.

BNV [Bambu Nusa Verde]. 2019. PT. Bambu Nusa Verde: plants in stock. drive.google.com/file/d/1IQyPJtxdZhyHGgePgAWhfPI4woJQQ5g8/ view?usp=drivesdk.

BPS [Badan Pusat Statistik]. 2017. Jumlah curah hujan dan jumlah hari hujan di stasiun pengamatan BMKG, 2011-2015. www.bps.go.id/statictable/2017/02/08/1959/jumlah-curah-hujan-danjumlah-hari-hujan-di-stasiun-pengamatan-bmkg-2011-2015.html. [Indonesian]

BPSKB [Badan Pusat Statistik Kabupaten Bengkalis]. 2018. Kabupaten Bengkalis dalam Angka 2018. BPS-Kabupaten Bengkalis, Bengkalis.

BPSKKS [Badan Pusat Statistik Kabupaten Kepulauan Selayar]. 2018. Kabupaten Kepulauan Selayar dalam Angka 2018. BPS-Kabupaten Kepulauan Selayar, Benteng.

BPSPNTB [Badan Pusat Statistik Provinsi Nusa Tenggara Barat]. 2018. Provinsi Nusa Tenggara Barat dalam Angka (Nusa Tenggara Barat Province in Figures) 2018. BPS Provinsi Nusa Tenggara Barat, Mataram. 
Brearley FQ, Adinugroho WC, Cámara-Leret R, Krisnawati H, Ledo A, Qie L, Smith TEL, Aini F, Garnier F, Lestari NS, Mansur M, Murdjoko H, Oktarita S, Soraya E, Tata HL, Tiryana T, Trethowan LA, Wheeler CE, Abdullah M, Aswandi, Buckley BJW, Cantarello E, Dunggio I Gunawan H, Heatubun CD, Arini DID, Istomo, Komar TE, Kuswand R, Mutaqien Z, Pangala SR, Ramadhani, Prayoto, Puspanti A, Qirom MA, Rozak AH, Sadili A, Samsoedin I, Sulistyawati E, Sundari S, Sutomo, Tampubolon AP, Webb CO. 2019. Opportunities and challenges for an Indonesian forest monitoring network. Ann For Sci 76 (54): 1-12.

$\begin{array}{llll}\text { Clark LG. } 2006 . & \text { Bamboo biodiversity. }\end{array}$ www.eeob.iastate.edu/research/bamboo/index.html.

Clark LG, Londono X, Ruiz-Sanchez E. 2015. Bamboo taxonomy and habitat. In: Liese W, Köhl M (eds.). Bamboo the Plant and its Uses. Springer, Cham

Damayanto IPGP, Widjaja EA. 2016. A new species of Schizostachyum (Poaceae: Bambusoideae) from Sumba Island, Indonesia. Reinwardtia 15 (2): $119-122$.

Damayanto IPGP, Rahmawati K. 2020. Bamboos diversity in Banggai Kepulauan, Central Sulawesi, Indonesia. J Biodjati 5 (1): 1-14.

Djarwaningsih T, Sunarti S, Kramadibrata K. 2002. Panduan Pengolahan dan Pengelolaan Material Herbarium serta Pegendalian Hama Terpadu di Herbarium Bogoriense. Herbarium Bogoriense, Bidang Botani, Pusat Penelitian Biologi, LIPI, Bogor. [Indonesian]

Dransfield S. 1995. Schizostachyum jaculans Holttum. In: Dransfield S, Widjaja EA (eds.). Plant Resources of South-East Asia. Backhuys, Leiden.

Dransfield S. 1996. New species of Dinochloa (Gramineae-Bambusoideae) in Malesia and notes on the genus. Kew Bull 51 (1): 103-117.

Dransfield S, Widjaja EA. 1995. Plant Resources of South-East Asia, No. 7. Bamboos. Backhuys, Leiden.

Girmansyah D, Santika Y, Suratman. 2006. Index Herbariorum Indonesianum. Pusat Penelitian Biologi, LIPI, Bogor.

Girmansyah D, Santika Y, Rugayah, Rahajoe JS. 2018. Index Herbariorum Indonesianum. LIPI Press, Jakarta.

Hasanah A. 2017. Model Spasial Restorasi Ekologi pada Hutan Hujan Tropis Banggai Kepulauan. [Hon. Thesis]. Indonesia University, Depok. [Indonesian]

Holmgren PK, Keuken W, Schofield EK. 1981. Index Herbariorum, the Guide to the Location and Contents of the World's Public Herbaria, Part I: the Herbaria of the World, 7th ed. Bohn, Scheltema \& Holkema, Utrecht.

Holttum RE. 1953. A Malayan blow-pipe bamboo. Kew Bull. 8 (4): 493-496.

Huzaemah, Mulyaningsih T, Aryanti E. 2016. Identifikasi bambu pada daerah aliran sungai Tiupupus Kabupaten Lombok Utara. J Bio Trop 16 (2): 23-36. [Indonesian]

Janzen DH. 1979. Why bamboos wait so long to flower. Ann Rev Ecol Syst 7 (1): 347-391.

Judziewicz EJ, Clark LG, Londono X, Stern MJ. 1999. American Bamboos. Smithsonian Institution, Washington DC

Liana A, Purnomo, Sumardi I, Daryono BS. 2017. Bamboo species (Poaceae: Bambusoideae) from Selayar Island. Floribunda 5 (6): 185-191.

Londono X. 2001. The cultural significance of Guadua angustifolia in Colombia. Bamboo Mag Amer Bamboo Soc 22 (5): 7.

McClure FA. 1945. Suggestions on How to Collect Bamboos. Division of Latin American Agriculture, Office of Foreign Agricultural Relations, Washington DC.

Mentari M, Mulyaningsih T, Aryanti E. 2018. Identifikasi bambu di sub daerah aliran sungai Kedome Lombok Timur dan alternatif manfaat untuk konservasi sempadan sungai. J Pen Pengelolaan Daerah Aliran Sungai 2 (2): 111-122. [Indonesian]

Munawarah A, Mulyaningsih T, Aryanti E. 2019. Inventarisasi bambu di daerah aliran sungai Semoya Lombok Barat. BioWallacea J Ilmiah Ilmu Biologi 5 (2): 80-91. [Indonesian]

Peneng IN, Pedas IN, Suteja INR. 2005. Eksplorasi Bambu di Kabupaten Lombok Tengah Nusa Tenggara Barat. Laporan Teknik Program Perlindungan dan Konservasi Sumber Daya Alam, Kebun Raya "Eka Karya" Bali 2005, Bali. [Indonesian]

Prawiroatmodjo S, Padmono. 1976. Laporan Perjalanan ke Lombok. Herbarium Bogoriense, Bogor. [Indonesian]

Putri RJC, Mulyaningsih T, Aryanti E. 2016. Identifikasi bambu di daerah aliran sungai Meninting Lombok Barat. BioWallacea J Ilmiah Ilmu Biologi 2 (2): 97-101. [Indonesian]

Rijaya I, Fitmawati. 2019. Jenis-jenis bambu (Bambusoideae) di Pulau Bengkalis, Provinsi Riau, Indonesia. Floribunda 6 (2): 41-52. [Indonesian]

Rini DS. 2018. Sifat fisika bambu petung (Dendrocalamus asper
(Schult.f.) Backer ex Heyne) dari KHDTK (Kawasan Hutan Dengan Tujuan Khusus) Senaru berdasarkan posisi aksial. J. Belantara 1 (2): 101-106. [Indonesian]

Rini DS, Wulandari FT, Aji IML. 2017. Studi jenis dan sebaran bambu di Kawasan Hutan Dengan Tujuan Khusus (KHDTK) Senaru. J Sangkareang Mataram 3 (4): 37-41. [Indonesian]

Rizkillah MA. 2018. Inventarisasi Hasil Hutan Bukan Kayu Bambu di Hutan Kemasyrakatan Senggigi Kabupaten Lombok Barat. [Hon. Thesis]. Mataram University, Mataram. [Indonesian]

Rugayah, Retnowati A, Windadri FI, Hidayat A. 2004. Pengumpulan data taksonomi. In: Rugayah, Widjaja EA, Praptiwi (eds.). Pedoman Pengumpulan Data Keanekaragaman Flora. Pusat Penelitian BiologiLIPI, Bogor. [Indonesian]

Rustiami H, Sulistyaningsih LD. 2020. Checklist flora of Lombok: Commelinids clade. In: Tihurua EF, Trethowan L (eds.). Checklist Flora of Lombok. Herbarium Bogoriense, Research Center for Biology, Indonesian Institute of Sciences, Cibinong, Bogor.

Santi DM, Mulyaningsih T, Aryanti E. 2019. Identifikasi bambu di sempadan sungai Keremit Resort Joben Taman Nasional Gunung Rinjani Lombok. J Biol Trop 19 (2): 239-249. [Indonesian]

Sinauer. 2010. Where is the world's biological diversity found? www.sinauer.com/media/wysiwyg/samples/PrimackEssentials5e_Ch0 3.pdf.

Soenarko S. 1977. A new species of Nastus Nees (Gramineae) from Sumba. Gard Bull Sing 30: 17-19.

Soreng RJ, Peterson PM, Romaschenko K, Davidse G, Teisher JK, Clark LG, Barbera P, Gillespie LJ, Zuloaga FO. 2017. A worldwide phylogenetic classification of the Poaceae (Gramineae) II: an update and a comparison of two 2015 classifications. J Syst Evol 55 (4): 259-290.

Steenis-Kruseman MJV. 1950. Malaysian plant collectors and collections. Fl Mal 1 (1): 1-639.

Susan D, Rugayah, Rustiami H, Mansur M, Rahayu M, Mahyuni R, Windadri FI, Kuncari ES, Murniati DC, Amir M, Kurnianingsih, Jaenudin. 2018. Laporan Perjalanan ke Kawasan Ekonomi Khusus Mandalika dan Sekitarnya (KSK Keanekaragaman Biota dan Potensi Biota di Nusa Tenggara). Pusat Penelitian Biologi-LIPI, Cibinong. [Indonesian]

TBNV [Tokopedia Bambu Nusa Verde]. 2018. Bibit bambu kolombia berduri (Guadua angustifolia) kultur jaringan. www.tokopedia.com/bambunusaverde/bibit-bambu-kolombiaberduri-guadua-angustifolia-kultur-jaringan. [Indonesian]

Tobe H, Shinohara W, Utami N, Wiriadinata H, Girmansyah D, Oginuma K, Azuma H, Tokuoka T, Kawaguchi E, Kono M, Ito M. 2010. Plant diversity on Lombok Island, Indonesia: an approach at identification using DNA barcodes. Acta Phyt Geobot 61 (2): 93-108.

Voogd CNAD. 1941. Botanische aanteekeningen van de Kleine Soenda Eilanden (IX): de Rindjani op Lombok. De Trop Nat 30 (7): 97-105.

Vorontsova M, Clark LG, Dransfield J, Govaerts R, Baker WJ. 2016. World checklist of bamboo and rattans. Inbar Tech Rep 37: 1-454.

Widjaja EA. 1987. A revision of Malesian Gigantochloa (PoaceaeBambusoideae). Reinwardtia 10 (3): 291-380.

Widjaja EA. 1997. New taxa in Indonesian bamboos. Reinwardtia 11 (2): $57-152$.

Widjaja EA. 2001a. Identikit Jenis-jenis Bambu di Kepulauan Sunda Kecil. Pusat Penelitian dan Pengembangan Biologi-LIPI, Bogor. [Indonesian]

Widjaja EA. 2001b. Identikit Jenis-jenis Bambu di Jawa. Pusat Penelitian Biologi-LIPI, Bogor. [Indonesian]

Widjaja EA. 2019. The spectacular Indonesian bamboos. Pola Aneka Sejahtera (Polagrade), Jakarta.

Widjaja EA, Astuti IP, Arinasa IBK. 2004. New species of bamboos (Poaceae-Bambosoideae) from Bali. Reinwardtia 12 (2): 199-204.

Widjaja EA, Astuti IP, Arinasa IBK, Sumantera IW. 2005. Identifikasi Bambu di Bali. Bidang Botani, Pusat Penelitian Biologi-LIPI, Bogor. [Indonesian]

Widyatmoko D, Suryana N, Suhatman A, Rustandi B. 2010. List of Living Plants Collection Cultivated in Cibodas Botanic Gardens. Cibodas Botanic Gardens, Indonesian Institute of Sciences, Cianjur.

Wong KM. 1995. The bamboos of Peninsular Malaysia. Malay For Res 41: $1-200$.

Wong KM. 2004. Bamboo the Amazing Grass, a guide to Diversity and Study of Bamboos in Southeast Asia. International Plant Genetic Resources Institute (IPGRI) and University of Malaya, Malaysia.

Wong KM, Dransfield S. 2016. Ruhooglandia and Widjajachloa, two new genera of Malesian bamboos (Poaceae: Bambusoideae) and their distinction from Nastus and Chloothamnus. Sandakania 22: 1-9. 